\title{
Defect Detection of Ceramic Tiles using Median Filtering, Morphological Techniques, Gray Level Co- occurrence Matrix and K-Nearest Neighbor Method
}

\author{
Riza Alamsyah \\ Department of Computer Science, Faculty of Information Technology, Budi Luhur University \\ Jakarta, Indonesia \\ izarizaalamsyah@gmail.com \\ Ade Davy Wiranata \\ Department of Computer Science, Faculty of Information Technology, Budi Luhur University \\ Jakarta, Indonesia \\ 1611602176@ student.budiluhur.ac.id \\ Rafie \\ Department of Computer Science, Faculty of Information Technology, Budi Luhur University \\ Jakarta, Indonesia \\ rafiekom@gmail.com
}

DOI: $10.31364 /$ SCIRJ/v7.i4.2019.P0419632

http://dx.doi.org/10.31364/SCIRJ/v7.i4.2019.P0419632

\begin{abstract}
Manufacturing industry companies must be able to maintain the quality of each product produced, including manufacturing companies that produce ceramic tiles. For several years, automatic visual inspection has been applied to determine the quality of ceramic tiles produced. The difficulty of detecting defective ceramic tiles can have an impact on decreasing the quality of production, decreasing the level of consumer confidence, and decreasing profits for the company. The problem discussed in this research is how to defect detection of ceramic tiles so that the model built can improve accuracy to defect detection of ceramic tiles. The solution to this problem is to collect data in the form of ceramic tiles images, then preprocessing images data using Median Filtering to eliminate salt and paper noise and Morphological Techniques to improve images segmentation results. After preprocessing, texture image extraction data is based on texture using the Gray Level Cooccurrence Matrix (GLCM) method which is continued by classifying images data using the K-Nearest Neighbor (KNN) method. The results of this research are models that are built using the Median Filtering, Morphological Techniques, Gray Level Cooccurrence Matrix and K-Nearest Neighbor method can improve accuracy to defect detection of ceramic tiles with an accuracy value of $98.9474 \%$ for $k=3$.
\end{abstract}

Keywords- Digital Image Processing, Median Filtering, Morphological Techniques, GLCM dan KNN.

\section{INTRODUCTION}

Nowadays, almost all industrial companies engaged in manufacturing are faced with a problem, namely the increasingly competitive level of competition. Industrial companies are required to produce quality products in order to meet market demand, so that the profits of industrial companies are expected to increase [13].

Manufacturing industry companies must be able to maintain the quality of each product produced, including manufacturing companies that produce ceramic tiles. The control process is one of the important issues in competition between ceramic industry producers and affects prices by looking at the purity of the texture, color accuracy, and shape [19]. During the process of producing ceramic tiles, the use of different raw materials and a long process has resulted in some ceramic tiles experiencing defects on the surface of ceramic tiles [13].

For several years, automatic visual inspection has been applied to determine the quality of ceramic tiles produced. The complexity of detecting defective ceramic tiles is still possible in automatic visual inspection [19]. With increasing consumer demand, from the perspective of quality and quantity, the use of automatic visual inspection is one of the key technologies in the manufacturing industry [18].

Research from [13] applied Artificial Neural Networks and the Backpropagation algorithm applied to Matlab Software with the results of this study showing an accuracy of almost $90 \%$. Whereas [3] conducts research by applying a mechanism based on the process of detecting dimensional defects, specifically rectangular defects with extraction of form features using morphological techniques. After the morphology technique, it was continued by using feature feature extraction and spatial information to get a clear edge position from the side of the ceramic tile and special coordinate points for the defect 
ISSN 2201-2796

measurement process. The results of this study indicate an accuracy value of $67 \%$.

The research conducted [17] proposed an algorithm that divides ceramic images into partitions and identifies defective partitions. Furthermore, the classification algorithm is only applied to defective partitions. Simulation results show an accuracy rate of $72 \%$. According to [5], detection of defects can be detected using the Rotation Invariant Measure of Local Variance (RIMLV) operator from the statistical method. All detected ceramic tiles are labeled and the geometry features that are suitable are extracted, then classified using Support Vector Machine (SVM). The results of this research indicate an accuracy value of $93.4 \%$.

Research conducted [21] proposed an automatic inspection system for the ceramic tile industry based on image processing techniques. This system can detect color variations and defects such as angle damage, edge damage and middle cracks on the tile surface. Tiles are compared with good quality reference tiles using the image processing concept using Matlab software. The results of this research indicate an accuracy value of $96.36 \%$.

Based on the descriptions in the background above, it can be identified that the problem, among others, is the difficulty of detecting defective ceramic tiles which can have an impact on decreasing the quality of production, decreasing the level of consumer confidence, and decreasing profits for the company. So the problem that can be discussed in this reasearch can be formulated as "How to detect defective ceramic tiles". The limitation of the problem in this research is the form of ceramic tiles used as square objects, the level of disability that will be detected in the form of lines and clumps, the ceramic tiles used are Mulia Artic type, the ceramic tiles used are not patterned (plain), and the size of ceramic tiles is $30 \mathrm{~cm}$ x $30 \mathrm{~cm}$. The purpose of this research is that the model built can improve the accuracy of disability detection in ceramic tiles using the Median Filtering method, Morphological Technique, Gray Level Cooccurrence Matrix and K-Nearest Neighbor.

\section{METHODOLOGY}

\section{A. DIGITAL IMAGE PROCESSING}

Digital Image Processing is a discipline that studies techniques in image processing. Image is a photo (still image) and video (moving image), while digital is a digital image or image processing using a computer [23]. Images that are presented numerically with discrete values can be processed with a digital computer. Image digitization is repersent from continuous functions to discrete values [11].

\section{B. K-NEAREST NEIGHBOR (KNN)}

K-Nearest Neighbor (KNN) algorithm is an algorithm that is used to classify an object based on the data closest to the object. Terms of value that is not greater than the amount of training data, the value must be odd and more than one [4]. K-Nearest Neighbor (KNN) algorithm is an algorithm that is used to classify an object based on learning data that is the closest distance to the object [10].

Euclidean distance is proximity in unit of distance matrix. Euclidean distance can be searched using equation (1) [4].

$$
\mathrm{D}_{\mathrm{XY}}=\sqrt{\sum_{\mathrm{i}=1}^{\mathrm{n}}\left(\mathrm{x}_{\mathrm{i}}-\mathrm{y}_{\mathrm{i}}\right)^{2}}
$$

where $\mathrm{D}=$ Proximity distance, $\mathrm{x}=$ training data, $\mathrm{y}=$ testing data, $\mathrm{n}=$ number of individual attributes between 1 through $\mathrm{n}, \mathrm{f}=$ similitary function of attributes $\mathrm{i}$ between case $\mathrm{X}$ and case $\mathrm{Y}$.

\section{GRAY LEVEL CO-OCCURRENCE MATRIX (GLCM)}

Texture is a characteristic or characteristic possessed by a region that is large enough so that naturally these characteristics or characteristics can be repeated in the area. Texture is the regularity of certain patterns formed from the arrangement of pixels in an image [1]. Kookurensi is a joint event, namely the number of occurrences of one level of a pixel value that is adjacent to one level of a pixel value in a certain distance (d) and angle $(\vartheta)$. Distance is expressed in pixels and the location is expressed in units of degrees. The orientation is done in four different angular directions with an angle interval $45^{\circ}$, which is $0^{\circ}, 45^{\circ}, 90^{\circ}$ and $135^{\circ}$. The distance between pixels is usually set at 1 pixel [20].

The research conducted [6] proposes various types of textural characteristics that can be extracted from the coefficient matrix, namely Energy or Angular Second Moment (ASM) which is expressed by equation (2), Contrast (Con) expressed by equation (3), Correlation (Cor ) which is expressed by equation (4), Homogeneity or Inverse Difference Moment (IDM) which is expressed by equation (5).

$$
\begin{gathered}
\text { ASM }=\sum_{\mathrm{i}} \sum_{\mathrm{j}}\{\mathrm{p}(\mathrm{i}, \mathrm{j})\}^{2} \\
\text { Con }=\sum_{\mathrm{k}} \mathrm{k}^{2}\left[\sum_{\mathrm{i}} \sum_{\mathrm{j}} \mathrm{p}(\mathrm{i}, \mathrm{j})\right], \quad|\mathrm{i}-\mathrm{j}|-\mathrm{k} \\
\text { Cor }=\frac{\sum_{\mathrm{i}} \sum_{\mathrm{j}}(\mathrm{ij}) \cdot \mathrm{p}(\mathrm{i}, \mathrm{j})-\mu_{\mathrm{x}} \mu_{\mathrm{y}}}{\sigma_{\mathrm{x}} \sigma_{\mathrm{y}}} \\
\text { IDM }=\sum_{\mathrm{i}} \sum_{\mathrm{j}} \frac{1}{1+(\mathrm{i}-\mathrm{j})^{2}} \mathrm{p}(\mathrm{i}, \mathrm{j})
\end{gathered}
$$

\section{MORPHOLOGICAL TECHNIQUES}

Morphological techniques represent the image of a twodimensional object as a mathematical set in Euclidean space which is seen as a set. An image object A can be represented in the form of a set of positions $(\mathrm{x}, \mathrm{y})$ which are worth 1 or 0 . These values indicate the grayscale level for each position. Value 1 for white gray level and value 0 for black gray level [7].

The basic principle of morphological techniques is the use of structuring elements which are the basic forms of an object that are used to analyze the geometric structure of other larger and more complex objects. The purpose of the morphology technique is to obtain information about the shape of an image by adjusting the size and shape of a structuring element. Structuring elements also have a pivot point (also called a origin / origin / reference point) [7].

\section{E. MEDIAN FILTERING}


Median Filtering is a method that focuses on the middle value of the total value of the overall pixel around it. The median filtering process begins by sorting the values of neighboring pixels first, then selecting the middle value [7].

\section{SYSTEM DESIGN AND APPLICATION}

The data used in this study are primary data obtained from photographing directly which will be used as a dataset. The dataset will be divided into 2, training data and testing data. In this study there were 190 training data consisting of 86 data for class images of good quality ceramic tiles and 104 data for class images of defective ceramic tiles. While the testing data amounted to 95 data, which consisted of 43 data for class images of good quality ceramic tiles and 52 data for class images of defective ceramic tiles.

The design of the model in solving the problem in this study by utilizing digital image processing in the form of Median Filtering and Morphological Techniques, the classification of KNN has already been carried out with texture-based feature extraction with GLCM. The model design is presented in Figure 1.

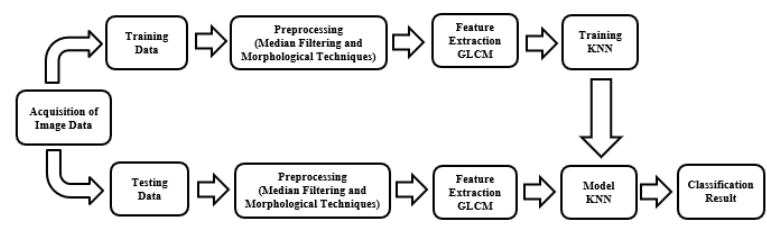

Figure 1: Model Design

Data acquisition in this study is by taking images directly using a mobile camera. Then the data is divided into two types of data, namely training data and testing data. Preprocessing stage aims to process the image so that its characteristics can be taken, eliminate noise and improve the results of image segmentation. At this stage the noise elimination technique is also carried out using the median filtering method and improving the results of image segmentation using Morphological Technique. Then texture-based feature extraction is performed using GLCM and classified using $\mathrm{KNN}$, so that the classification results are obtained whether the image of ceramic tiles including the image of fine ceramic tiles or defects.

\section{EXPERIMENTAL RESULTS}

In this study there were 190 training data consisting of 86 data for class images of good quality ceramic tiles and 104 data for class images of defective ceramic tiles. While the testing data amounted to 95 data, which consisted of 43 data for class images of good quality ceramic tiles and 52 data for class images of defective ceramic tiles. Image of ceramic tiles obtained by photographing ceramics obtained from PT. Beautiful Ceramics by using a cellphone camera and stored in .jpg form to be able to train training data and testing data.

Model making in this research was carried out using Matlab R2017a. The screen display in the defect detection model on ceramic tiles can be seen in Figure 2.

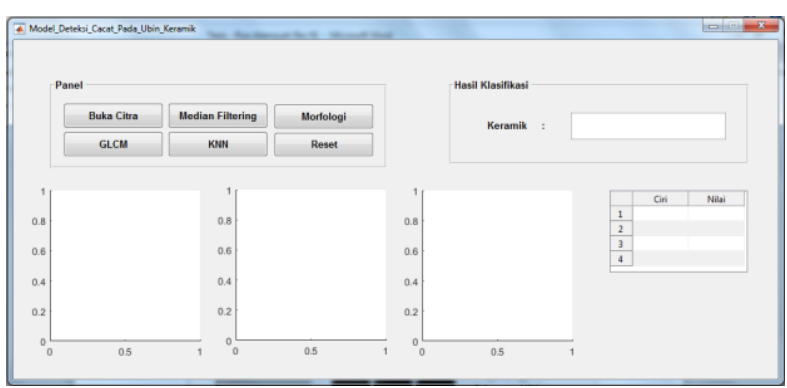

Figure 2: Model of Defect Detection of Ceramic Tiles

In Figure 2 can be seen in the panel there are 6 types of options, namely the option "Open Image", "Median Filtering", "Morphology", "GLCM", "KNN" and "Reset". The image of ceramic tiles that you want to classify can be chosen by selecting the "Open Image" option, then the image of the selected ceramic tile will be displayed in the "Original Image" section. Next select the option "Median Filtering" to remove the noise and select "Morphology" to improve the results of image segmentation.

Then select the "GLCM" option for extracting features based on texture. The value of the extraction of texture features will be displayed in the table section shown in Figure 2. Classification is done by selecting the "KNN" option whose results will be displayed in the "Classification Results" section, image of selected ceramic tiles including good quality ceramic tiles or disabled. If you want to test the image of other ceramic tiles, you can choose the "Reset" option before re-selecting the "Open Image" option. The screen display of the defect detection model on ceramic tiles is shown in Figure 2.

Figure 3 shows the original image, the median filtering result, the results of the morphological technique, the results of feature extraction with GLCM and the classification results of the KNN whose original image is a ceramic tile with good quality.

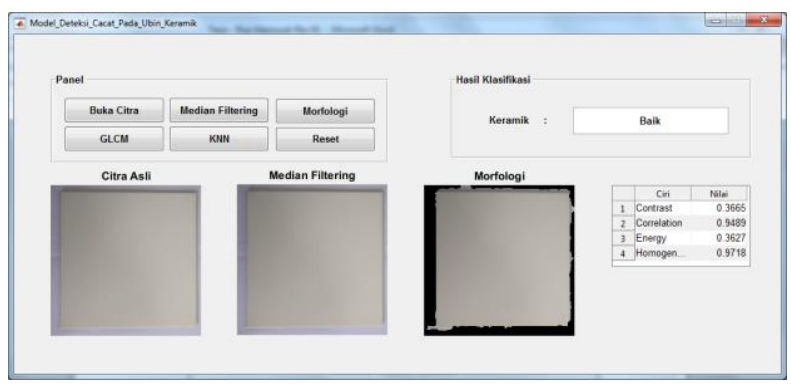

Figure 3: Model of Defect Detection of Good Ceramic Tiles

Figure 4 displays the original image, the median filtering result, the results of the morphological technique, the results of feature extraction with GLCM and the classification results of the KNN whose original image is a ceramic tile with defective quality. 


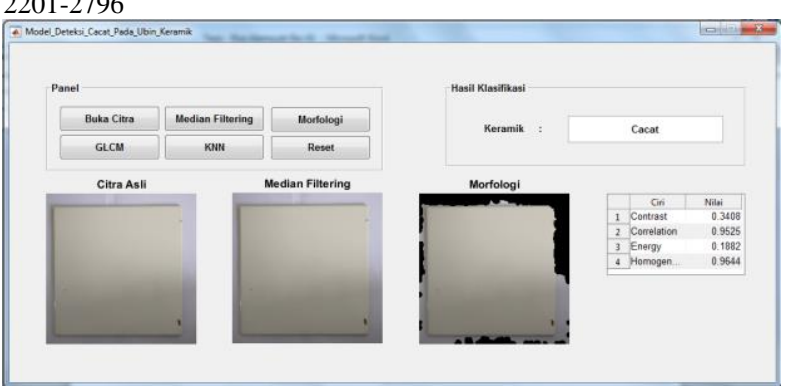

Figure 4: Model of Defect Detection of Defective Ceramic Tiles

In this research, there were 1 prediction error from 95 testing data with 43 test data on the image of good quality ceramic tiles and 52 test data on the image of quality defective ceramic tiles.

The results of testing the defect detection model on ceramic tiles using the Confusion Matrix for all $\mathrm{k}$ values tested are presented in Table 1.

Table 1. Value of Accuracy Model of Defect Detection

\begin{tabular}{|l|c|}
\hline $\begin{array}{c}\text { Value of } \\
\mathbf{k}\end{array}$ & \multicolumn{1}{c|}{$\begin{array}{c}\text { Accuracy } \\
\text { Result }\end{array}$} \\
\hline $\mathrm{k}=3$ & $98.9474 \%$ \\
\hline $\mathrm{k}=5$ & $94.7368 \%$ \\
\hline $\mathrm{k}=7$ & $94.7368 \%$ \\
\hline $\mathrm{k}=9$ & $93.6842 \%$ \\
\hline $\mathrm{k}=11$ & $93.6842 \%$ \\
\hline $\mathrm{k}=13$ & $93.6842 \%$ \\
\hline $\mathrm{k}=15$ & $91.5789 \%$ \\
\hline
\end{tabular}

Based on Table 1, it can be said that the defect detection model in ceramic tiles has the highest accuracy value for $\mathrm{k}=3$ which is $98.9474 \%$.

\section{CONCLUSION}

Based on the discussion of the results of the above research, it can be concluded that the model is built using the Median Filtering method, Morphological Technique, Gray Level Cooccurrence Matrix and K-Nearest Neighbor can improve accuracy to detect defects in ceramic tiles with an accuracy value of $98.9474 \%$ for $\mathrm{k}=3$.

Based on the results of the research and conclusions obtained, the suggestion that can be given as a reference for further research is that research can be continued using other different methods to measure accuracy so that the best results are obtained to detect defects in ceramic tiles.

\section{REFERENCES}

[1] Anggraini, R. (2017) "Klasifikasi Jenis Kualitas Keju Dengan Menggunakan Metode Gray Level Co-occurrence Matrix (GLCM) dan Support Vector Machine (SVM) Pada Citra Digital," 4(2), page. 2035-2042.

[2] Elbehiery, H., Hefnawy, A. and Elewa, M. (2007) "Surface Defects Detection for Ceramic Tiles Using Image Processing and Morphological Techniques," Proceedings of World Academy of Science, Engineering and Technology, Vol 5, 1(5).

[3] Gonydjaja, R. and Kusuma, T. M. (2014) "Rectangularity Defect Detection for Ceramic Tile Using Morphological Techniques," 9(11), page. 2052-2056.

[4] Han, J., Kamber, M. and Pei, J. (2012) "Data Mining Concepts and Technique." Waltham: Elsevier.

[5] Hanzaei, S. H. and Afshar, A. (2017) "Automatic Detection and Classification of the Ceramic Tiles' Surface Defects," Pattern Recognition. Elsevier, 66, page. 174189. doi: 10.1016/j.patcog.2016.11.021.

[6] Haralick, K., Shanmugam and Dinstein, I. (1973) "Textural Features For Image Classification," 3, page. $610-621$.

[7] Iriyanto, S. and Zaini (2004) "Pengolahan Citra Digital," (March 2014).

[8] Islam, M., Sahriar, R. and Hossain, B. (2012) "An Enhanced Automatic Surface and Structural Flaw Inspection and Categorization using Image Processing Both for Flat and Textured Ceramic Tiles," International Journal of Computer Applications, 48(3), page. 1-10. doi: 10.5120/7325-9159.

[9] Jacob, G., Shenbagavalli, R. and Karthika, S. (2016) "Detection of Surface Defects on Ceramic Tiles Based on Morphological Techniques." Available on: http://arxiv.org/abs/1607.06676.

[10] Kusrini, Emha, T. and Luthfi (2009) "Algoritma Data Mining." Yogyakarta: Andi.

[11] Kusumanto, R. D. and Tompunu, A. N. (2011) "Pengolahan Citra Digital Untuk Mendeteksi Obyek Menggunakan Pengolahan Warna Model Normalisasi RGB," Seminar Nasional Teknologi Informasi \& Komunikasi Terapan 2011, 2011(Semantik), page. 1-7.

[12] Li, X., Jiang, H. and Yin, G. (2014) "Detection of Surface Crack Defects on Ferrite Magnetic Tile," NDT and E International. Elsevier, 62, page. 6-13. doi: 10.1016/j.ndteint.2013.10.006.

[13] Nazelliana, D. (2014) "Deteksi Cacat Ubin Keramik Dengan Metode Jaringan Syaraf Tiruan dan Algoritma Backpropagation," 7(2), pagel. 154-164.

[14] Ndaumanu, R. I. (2014) "Analisis Prediksi Tingkat Pengunduran Diri Mahasiswa dengan Metode K-Nearest Neihbor," 1(1).

[15] Pamungkas, A. (2016) "Segmentasi Warna Citra Digital." Available on: pemrogramanmatlab.com/2016/11/09/segmentasi-warnacitra-digital/amp/.

[16] Putra, D. (2010) “Pengolahan Citra Digital." Yogyakarta: Andi.

[17] Ragab, K. and Alsharay, N. (2017a) "An Efficient Defect Classification Algorithm for Ceramic Tiles," 710. doi: 


$$
\text { 10.1007/978-3-319-56660-3. }
$$

[18] Ragab, K. and Alsharay, N. (2017b) "Developing Parallel Cracks and Spots Ceramic Defect Detection and Classification Algorithm Using CUDA," Proceedings 2017 IEEE 13th International Symposium on Autonomous Decentralized Systems, ISADS 2017, page. 255-261. doi: 10.1109/ISADS.2017.14.

[19] Rahaman, G. M. A. and Hossain, M. M. (2009) "Automatic Defect Detection and Classification Technique from Image: A Special Case Using Ceramic Tiles," Journal of Computer Science, 1(1), page. 9. Tersedia pada: http://arxiv.org/abs/0906.3770.

[20] Saifudin and Fadlil, A. (2015) "Sistem Identifikasi Citra Kayu Berdasarkan Tekstur Menggunakan Gray Level Coocurrence Matrix (GLCM) Dengan Klasifikasi Jarak Euclidean," Sinergi, 19, page. 181-186.

[21] Samarawickrama, Y. C. and Wickramasinghe, C. D. (2017) "Matlab based Automated Surface Defect Detection System for Ceremic Tiles using Image Processing," Proceedings of the 2017 6th National Conference on Technology and Management: Excel in Research and Build the Nation, NCTM 2017, page. 34-39. doi: 10.1109/NCTM.2017.7872824.

[22] Shao, X., Li, H., Wang, N. and Zhang, Q. (2015) "Comparison of Different Classification Methods for Analyzing Electronic Nose Data to Characterize Sesame Oils and Blends," Sensors (Switzerland), 15(10), page. 26726-26742. doi: 10.3390/s151026726.

[23] Sutoyo, T., Mulyanto, Edy, S., Vincent, D. N. O. and Wijanarto (2009) "Teori Pengolahan Citra Digital." Yogyakarta: Andi.

[24] Tania, S. and Rowaida, R. (2018) “A Comparative Study of Various Image Filtering Techniques for Removing Various Noisy Pixels in Aerial Image A Comparative Study of Various Image Filtering Techniques for Removing Various Noisy Pixels in Aerial Image," (March 2016). doi: 10.14257/ijsip.2016.9.3.10.

[25] Tim (2016) "Oneplus 3 Camera Review." Available on: https://www.droid-life.com/2016/06/22/oneplus-3-camerareview/. 